\title{
New Inscriptions from Smyrna
}

\author{
Akın ERSOY* - Ş. Recai TEKOĞLU**
}

Archaeological excavations in Smyrna, which was built as a harbour city at the slopes of Kadifekale (ancient Mount Pagos) after the arrival of Alexander the Great, have been conducted at Kadifekale, acropolis of Smyrna, in the agora and in the theatre of Smyrna in last 14 years since 2007. The epigraphic materials presented in this study have been acquired from both the excavations and the surface. These inscriptions formed a new collection after the publication of G. Petzl in Die Inschriften von Smyrna in IK 23 in 1982, 24.1 in 1987 and 24.2 in 1990. Some of the funerary inscriptions presented here were found in the agora excavations and collected as spolia material used on various modern buildings in the slopes of the acropolis. No archaeological excavation has been performed in the cemeteries of the ancient city yet.

\section{Funerary inscription of Asklepiades}

The rectangular fragmentary limestone block was found in the southern slope of the fire tower at Kadifekale, İzmir. It seems to be likely that the block was framed to be placed into the wall of a funerary architecture. It is partly damaged on the left-hand side as it was beaten in modern days. The block bears a Greek inscription of 7 lines. The letters and lines are sloppily formed in order and dimension. They are mostly angular and have conspicuous serifs. Apices of alpha, lambda and delta are elongated in most cases and sometimes emphasized with a small straight stroke. Alpha with dropped bar, epsilon with three oblique and equal bars, kappa with small oblique bars, slightly slanting $m u$, $p i$ with equal vertical strokes, square sigma, and omega with lower appendices developed to angular bar are the typical letters.

Inv. No: SMYRNA.4431 / SMKDF.2018.01 / KD.18.68 / Kadifekale SURFACE

H: $23.5 \mathrm{~cm}$; W: $37.5 \mathrm{~cm}$; D: $4.5 \mathrm{~cm}$; Lh: $2,5 \mathrm{~cm}$.

Date: $3^{\text {rd }}$ century $A D$ as per lettering

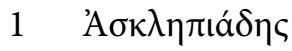

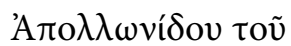

А $\pi \mathrm{o} \lambda\langle\lambda\rangle \omega v i \delta$ ov $\zeta \tilde{\omega} v$

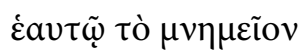

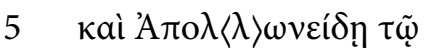

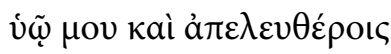

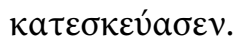

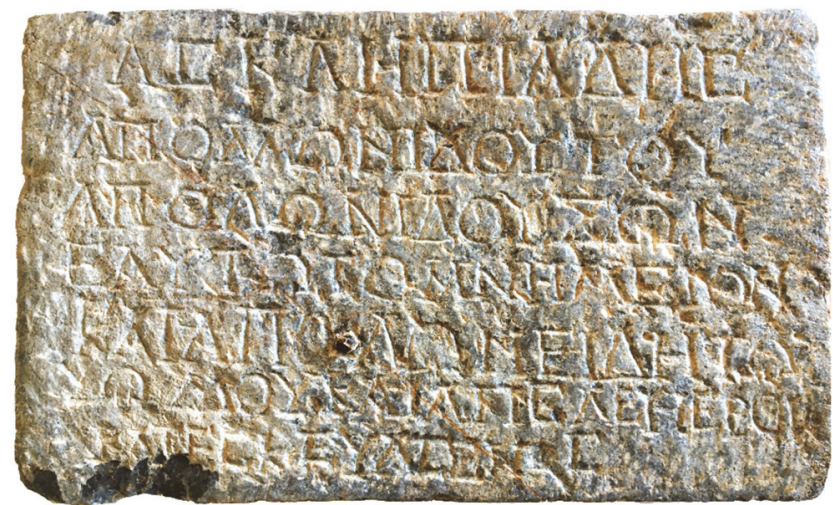

* Assoc. Prof. Dr. Akın Ersoy, the director of the Smyrna Agora Excavation, İzmir Katip Çelebi University, İzmir (akin.ersoy@ikcu.edu.tr; (D) https://orcid.org/0000-0001-9676-5865).

** Prof. Dr. Ş. Recai Tekoğlu, Dokuz Eylül University, İzmir (recai.tekoglu@deu.edu.tr; (Dhttps://orcid.org/0000-0002-7702-2625). 


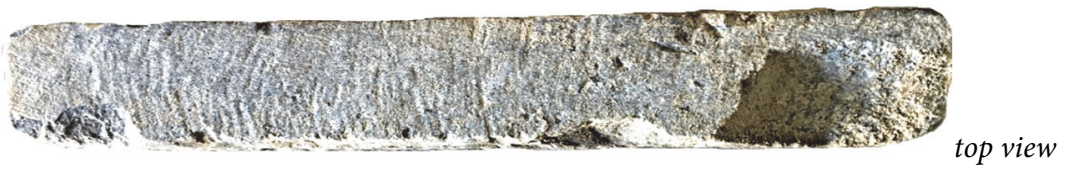

Translation: (I) Asklepiades, son of Apollonides, grandson of Apollonides, while I was alive, built the tomb for myself and my son Apollonides and freedmen.

1.3. A Ало $\lambda \lambda \omega v i \delta \eta\rceil$ was inscribed only with a single lambda and it was repeated in 1. 6. The use of the form with single lambda employed for the names of both the god Apollon and the theophoric personal names, such as Apollonios, Apollonides etc. is a quite rare. ${ }^{1}$ In line $5 \varepsilon$ was written for

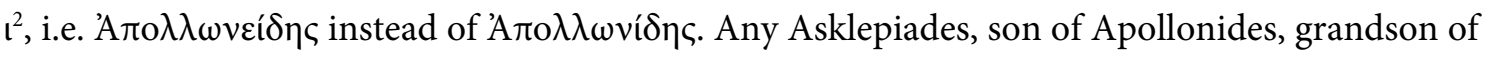
Apollonides is unknown in the inscriptions from Smyrna and Ionia.

1.6. $\dot{v} \tilde{\varphi}=v i \tilde{\varphi}$; That the $\mathrm{Y}$ and $\Theta$ are ligatured in $\alpha \dot{\pi} \varepsilon \lambda \varepsilon v \theta \varepsilon \dot{\varepsilon} \rho o$ ç does not seem to have been made intentionally, as the forms of these letters are not suitable for such a combination. The inscriber might have made an error while carving and fixed it in this way. Additionally, that the final sigma of the same word was carved at the end of the next line might also indicate a planning error, as there is enough space after the end of the following line to cut the word å $\pi \varepsilon \lambda \varepsilon v \theta \varepsilon \dot{\varepsilon} \rho$

\section{Funerary inscription of Aelius Iulius Philopator}

The fragmentary local grey limestone block trimmed off in rectangular form in a later period for spolia was found at Kadifekale. 7 lines of the inscription are preserved. Lines are regular and aligned at right: slightly pointed serifs, alpha with dropped bar, lunate epsilon and sigma, cursive $m u$, wide upsilon with short vertical bar, $p i$ with equal vertical bars, rho with small loop, phi with tall hasta and small loops, horse-shoe shaped omega with open mouth.

Inventory: SMYRNA.4569 / SMAG.2019.67 / KD.19.07 / SURFACE

H: 23,7 cm; W: $33 \mathrm{~cm}$; D: 11,9 cm; Lh: 2,3 cm.

Date: Roman imperial period, around the end of $2^{\text {nd }}$ century $\mathrm{AD}$ as per lettering.

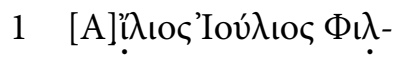

[o] $\pi \alpha ́ \tau \omega \rho \zeta \tilde{\omega} \nu \kappa a \tau \varepsilon-$

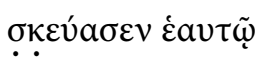

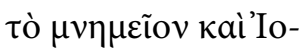

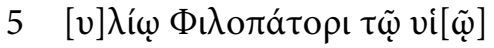

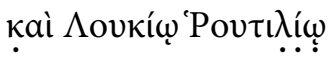

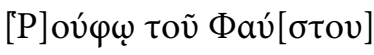

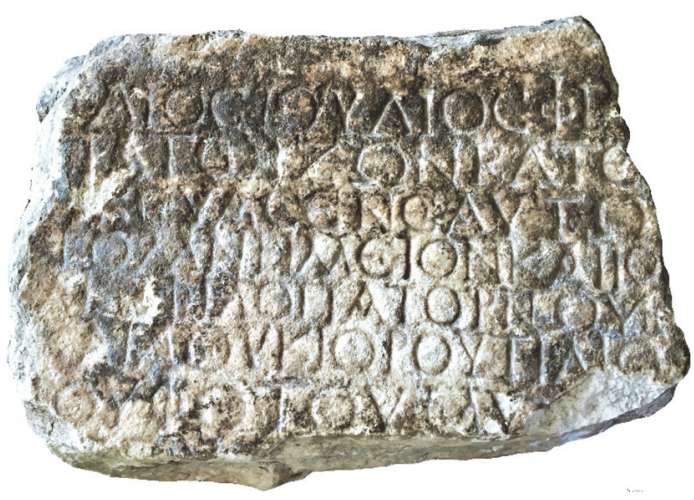

${ }^{1}$ Two examples are known from Smyrna: ISmyrna 164 ('A $\pi$ o $\left.\lambda \omega v i ́ o v\right)$ and 556 ('A $\left.\pi \mathrm{o} \lambda \omega v i ́ \delta o v\right)$. Though rare, this feature can be observed in the Greek inscriptions of antiquity, but more than half of these are attested in Asia Minor (see LGPN, s.v. and PHI). The switch between single lambda and double lambda can also be seen in different cases, such as Aloandeus and Alloandeus, ethnikon of the Lycian settlement Aloanda, see TAM II 526; Onur - Kılıç-Arslan 2021, 6 and 26-27.

${ }^{2}$ For the interchange of $\varepsilon$ เ and ı see Gignac 1976, I 189-191. 
Translation: Aelius Iulius Philopator, while he was alive, built the tomb for himself and (his) son Iulius Philopator and Lucius Rutilius Rufus, son of Faustus - - -

The owner of the monument is recorded as Aelius Iulius Philopator, who seems to have an irregular tria nomina. The praenomen stands as Aelius, which was originally a nomen gentilicium, and this seems to be rarely attested in the inscriptions from Smyrna ${ }^{3}$. His son is called Iulius Philopator sharing the same nomen gentilicium and cognomen with the father. He does not have a praenomen in the usual way of tria nomina and father's nomen gentilicium appears to be a praenomen for him. The cognomen Philopator is unknown in the inscriptions from Smyrna and represents the first attestation.

The tomb seems to contain multiple bodies beside the owner and his son. The type of the tomb may be a tomba a camera. The $3^{\text {rd }}$ recipient is recorded as Lucius Rutilius Rufus, son of a Faustus, who may have the same nomen gentilicium and cognomen with the son. His relationship with the tomb owner is unknown.

\section{Funerary inscription by Aurelia}

Figurative grave stele with a relief of farewell scene on the front and an inscription of 4 lines at the back, made of local limestone, was found at Altinpark. The style of the relief belongs to the category of Hellenistic steles from Smyrna. The upper part of the stele was cut away just below the frame around the relief. The heads of horse, tomb owner and his wife in the farewell scene were mutilated. It is very likely that a presentation by demos and name of deceased were incised on the lost pediment.

The back was flattened with tooth chisel cancelling an earlier inscription, which seems impossible to recover.

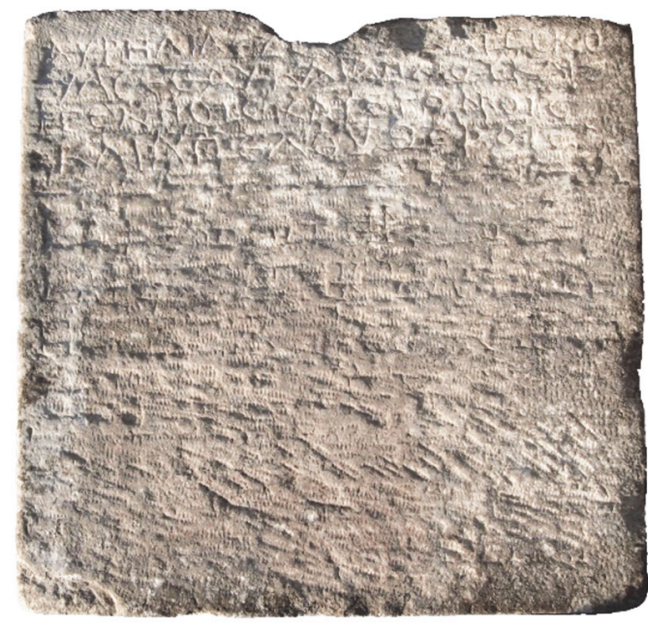
It is not habitual to incise an inscription on the back of a figurative grave stele from Smyrna in the Hellenistic period. It is possible that the erased earlier inscription must belong to a second use, and the survived last one must belong to a third use in the late $3^{\text {rd }}$ century $\mathrm{AD}$ or later. A hallow spot was curved in the middle at the upper part of the block and this seems be done for its use of spolia material.

Letters, line levels and syllabication are cursory in order and dimension. The letters are cut shal-

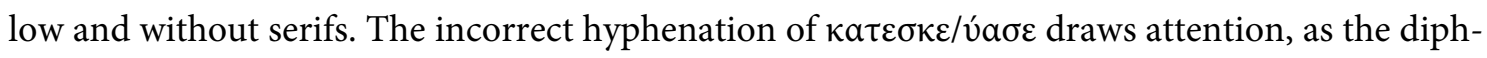
thong is divided. Alpha with oblique central bar at left, lunate epsilon and sigma, chalice-shaped upsilon, sometime with a small hasta, sometime without hasta, $p i$ with equal vertical strokes.

Inventory: SMYRNA. 1045/ SMBM. 2008. 442 (Basmane/Altınpark) A. Park. 08.103, E-3 grid, level: $9.20 \mathrm{~m}$.

H: 51,5 cm; W: $53 \mathrm{~cm}$; D: $11.5 \mathrm{~cm}$; Lh: $2.7 \mathrm{~cm}$.

Date: late $3^{\text {rd }}$ century $\mathrm{AD}$, or latter, as per lettering

Text: Ersoy - Laugier 2019, 73-74.

\footnotetext{
${ }^{3}$ An example can be seen in ISmyrna I, no. 232 for Aelius Bion.
} 


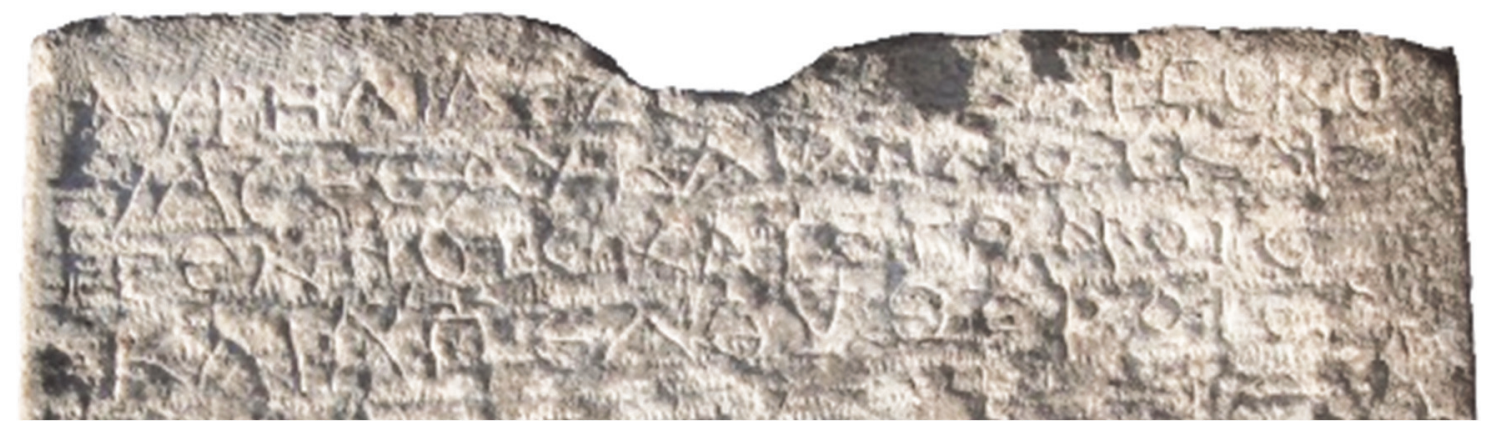

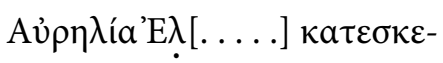

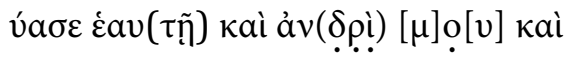

Translation: Aurelia El[. . . . . built

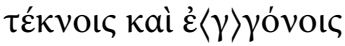

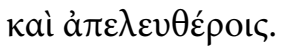

(this tomb) for myself and my husband

and children and descendants and freedmen.

L. 1. The tomb owner Aurelia s cognomen seems to be composed of ca. 7 letters. The previous editors of the inscription recognized its first two letters as $C \Delta$ without any description. The $8^{\text {th }}$ letter of the line is lunate epsilon and the $9^{\text {th }}$ letter is lambda. Its identification with delta is not probable as the trace which can be seen just below the sign seems to be a part of the chiseled alignment line, which begins just below the rho and can be followed to right below the sign in question. Thus, the first two letters of the cognomen are E $\Lambda$-. The following part of the line is

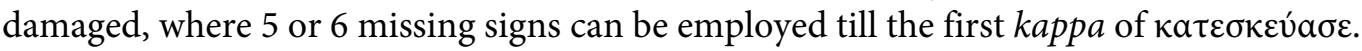

It is usual to see Greeks in Ionia received a Roman nomen gentilicium as praenomen like Aurelius or Aurelia after the Constitutio Antoniniana in $212 \mathrm{AD}$.

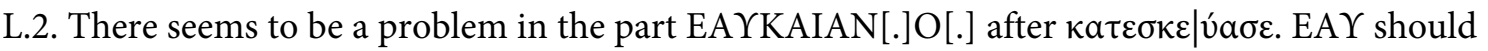
refer to $\dot{\varepsilon} \alpha v(\tau \tilde{\eta})$, then comes kaí. In the rest of this part, a word occurs with 5 traceable signs where the reading of alpha, nu and omicron seems to be secure. It was accepted as à $v(\delta \rho \grave{i}) \mu$ ov by the previous editors 4 .

L.3. a second gamma or kappa is omitted in غ̇үóvorc.

\section{Fragment of gravestone}

The fragmentary dark local limestone block was found in the agora of Smyrna. It includes 3 lines of inscription. The right-hand side of the inscription seems to be preserved. It has elongated and symmetrical letters; angular, straight and emphasized serifs; alpha with straight bar, theta with central short bar, rho with small loop, smaller omicron, phi with two small loops on both side of hasta, upsilon with horizontal stroke below the oblique strokes, horse-shoe omega.

H: $18,5 \mathrm{~cm}$; W: $28,9 \mathrm{~cm}$; $: 7,8 \mathrm{~cm}$; Lh: $3,6 \mathrm{~cm}$.

Inventory: SMYRNA.4753-B / SMTİ.2020.86-B / Tİ.20.83-B / C1-24 / 81.88-80.09 m.

Date: Roman imperial period as per lettering

\footnotetext{
${ }^{4}$ See the contribution of Laura Favreaux in Ersoy - Laugier 2019, 73.
} 


$$
\begin{aligned}
& \text { [ ]vọ́pı入os }
\end{aligned}
$$

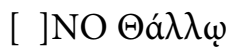

$$
\begin{aligned}
& \text { [ ] ] б }
\end{aligned}
$$

Translation: - -nophilos for foster/adopted son Thallos ---

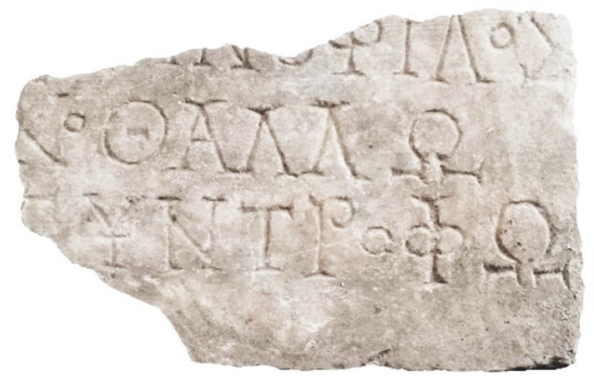

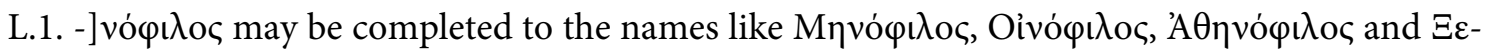

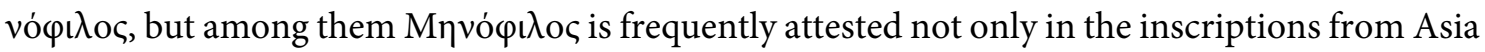
Minor, Ionia but also from Smyrna.

L.2. at the beginning of the line nu and small omicron are legible but it is quite uncertain to complete with any word. $\Theta a ́$ a $\lambda$ oc is likely a personal name, unknown so far in the inscriptions from Smyrna.

\section{Funerary or honorary inscription}

Fragmentary stele with angular pediment of local limestone was found in the agora of Smyrna, it is adorned with a disk at the centre. Sides and lower part are broken off and lost. A space in size of almost 2 letters is missing at the beginning of the first line. The stele surface is highly worn. Only a few of letters in the first two lines are hardly recognizable. Lettres are sloppy and without serifs: alpha with dropped bar, non-slanting sigma, lunate omega.

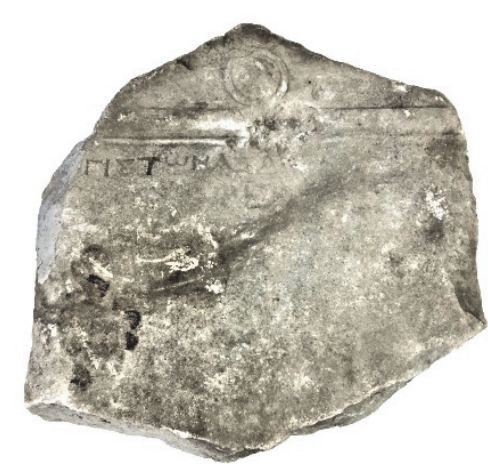

Inventory: SMYRNA.4252 / SMAG.2018.09 / KD.18.09 / Z1/A2-12/13 / SURFACE 14 m. $\mathrm{H}: 32,8 \mathrm{~cm}$; W: $32,7 \mathrm{~cm}$; D: $8 \mathrm{~cm}$; Lh: $2,2 \mathrm{~cm}$

Date: Roman imperial period as per lettering

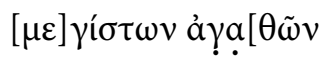

$$
\begin{aligned}
& \text { [ ] }][
\end{aligned}
$$

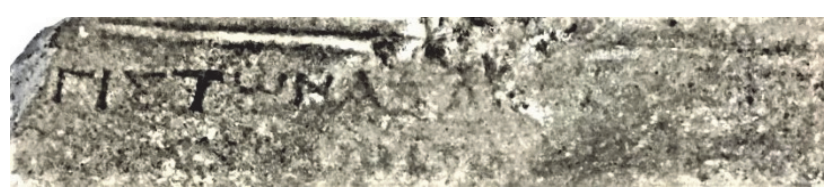

$1.1-\mu \varepsilon \gamma \dot{\sigma} \sigma \tau \omega v$ à $\gamma \alpha \theta \tilde{\omega} v$ seems to be a kind of qualification for persons to be honoured because of their responsible attitudes for greatest goods done on behalf of country or people. The text may

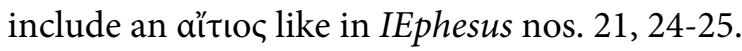

\section{Funerary or honorary inscription by demos}

Description: a piece of local dark limestone block found in the agora of Smyrna. Symmetric letter cuts with slight serifs; alpha with dropped bar, square epsilon with short middle bar, pi with equal vertical strokes, rho with small loop, non-slanting sigma.

Inventory: SMYRNA.4646-A / SMAG.2020.05-A / HAMAM.20.05-A / E1/F1-36 /12,95-11.26 m. H: $18.4 \mathrm{~cm}$; W: $17.8 \mathrm{~cm}$; D: $23 \mathrm{~cm}$; Lh: $3.4 \mathrm{~cm}$

Date: Roman imperial period as per lettering 


\section{A letter (?)}

Three joint fragments of limestone inscription were found in the northern street of the agora of Smyrna, where a series of lime pits were unearthed. It is probable that the inscription was carried away to the lime pits from somewhere near to the agora for dissolving lime. Only four lines are preserved in part. The remnants of signs in fifth line are not identifiable. Lines and line spaces are regular and straight. Letters are deeply cut with sharp apices, and the red colour of the painted letters survived in most of the letters. Alpha is with straight bar and detached oblique strokes; square epsilon is with short middle bar, and the apices at the ends of the upper and lower bars are carved with sharp and high serifs; sigma is in classical style and the apices are similar to those of epsilon; $p i$ is with equal vertical strokes and protruding horizontal stroke; circular part of omega stands slightly above its two bottom bars with sharp apices, but is connected to them; beta has equal loops; delta's horizontal stroke protrudes from its oblique bars; $n u$ and $m u$ are symmetrical; kappa is with large cross-bars; upsilon is chalice-shaped.

Inventory: SMYRNA.4196-A / SMAG.2017.125-A / KC.17.26-A / L2-36/37 Grid/ level:10,26 m. H: 17,4 cm; W: 27,4 cm; D: 3,4 cm; Lh: 2,6 cm.

Date: Roman imperial period as per lettering.
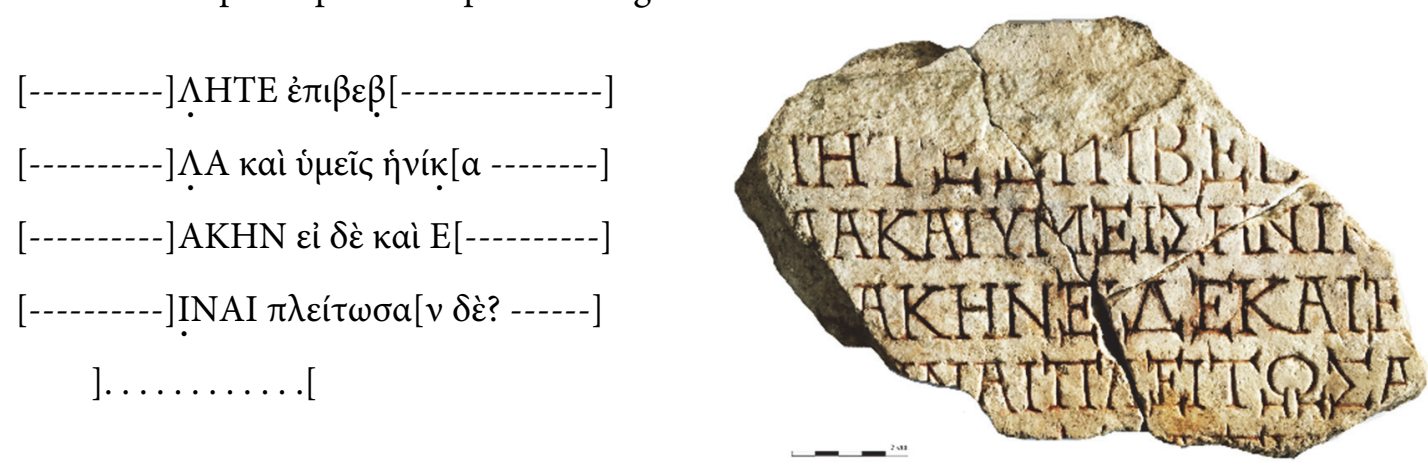

The inscription seems to be a letter on the basis of the preserved vocabulary, such as imperatives $-\Lambda$ HTE and $\pi \lambda \varepsilon i ́ \tau \omega \sigma \alpha v$, and $\dot{v} \mu \varepsilon \tilde{s}$. The content of the letter, sender and recipient cannot be deduced. A part of the text is related to sailing and shipping (1.4: $\pi \lambda \varepsilon i$ i $\omega \sigma \alpha v)$.

L.1. perhaps $[\pi \alpha \rho \alpha \kappa \alpha] \lambda \tilde{\eta} \tau \varepsilon \dot{\varepsilon} \pi \iota \beta \varepsilon \beta[\alpha \iota \tilde{\omega} \sigma \alpha \mathrm{l}$, call in to confirm/ratify...”.

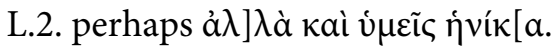

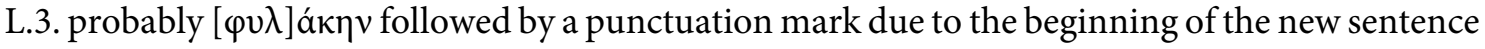
thereafter as $\varepsilon \grave{c} \delta \grave{\varepsilon}$ kaì...

L.4. the form of $\pi \lambda \varepsilon i ́ \tau \omega \sigma \alpha v$ is not attested in the inscriptions. An occurrence of this form in literary texts can be found in the histories of Polybius. ${ }^{7}$ The $3^{\text {rd }}$ person pl. imperative ending in $-\tau \omega \sigma \alpha v$ is used after Thucydides, and in the inscriptions after $300 \mathrm{BC}^{8}$.

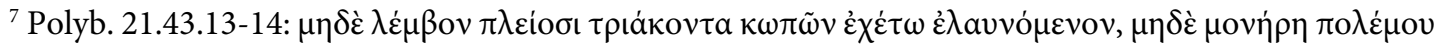

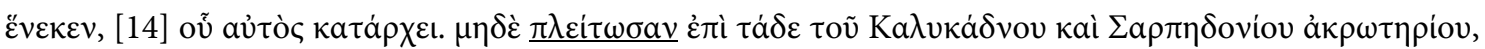

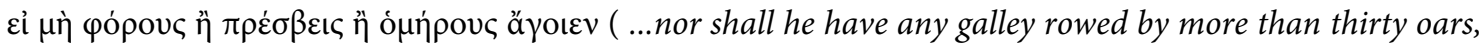
nor a moneres to serve in any war in which he is the aggressor: his ships shall not sail beyond the Calycadnus and the Sarpedonian promontory unless conveying tribute, envoys or hostages... Trans. from LOEB edition).

${ }^{8}$ See Smyth 1956, $\$ 466.3$. 


\section{Place inscription of Bassus and the children of Thessalonike}

The inscription was carved on the wall of doorway to stage room in the theatre of Smyrna. It is a place inscription in tabula ansata incised on a cut stone block located in the southern wall of the room M6 in the $1^{\text {st }}$ floor of the theatre. Another inscription was added possibly in latter times below the place inscription inside the tabula ansata contains a few of unidentifiable letters. Lines are aligned at left. Syllable division is regular. Letters are symmetrical and carefully cut. Vertical and oblique strokes have small horizontal serifs. The features of letters as follow: Alpha with dropped bar, lunate sigma and epsilon, cursive omega, theta with short central bar, smaller omicron, $p i$ with equal vertical strokes, chalice-shaped upsilon with short horizontal bar below the oblique strokes. A leaf hanging down is depicted at the end of the inscription.

H: $25 \mathrm{~cm}$; W: $35 \mathrm{~cm}$. Lh: $3.5 \mathrm{~cm}$.

Date: Roman imperial period as per lettering

a)

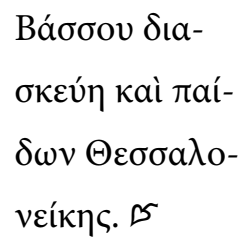

b)

$$
[\ldots] \mathrm{OP}[. .] \mathrm{O} \Sigma
$$

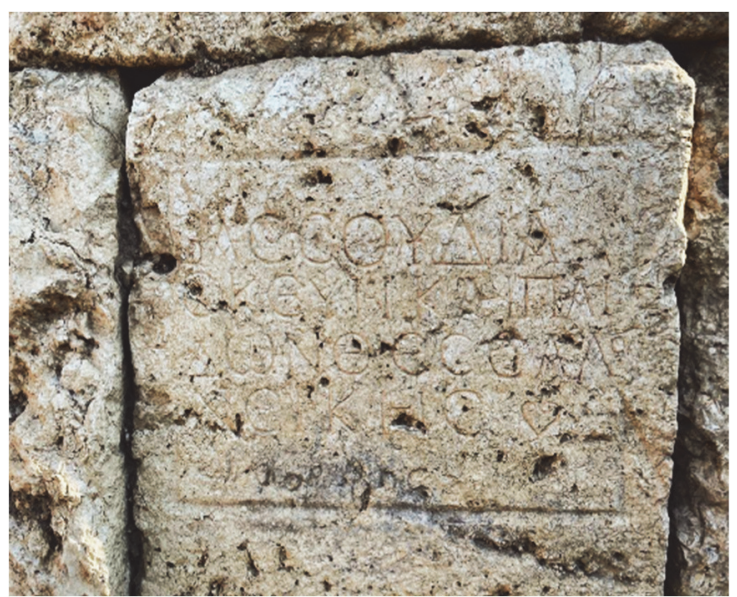

Translation: Equipment of Bassus and the children of Thessalonike.

Such place inscriptions usually belong to the performers (see also below no. 10). ${ }^{9}$ No information about Bassus and the children of Thessalonike as actors is known in the inscriptions from Smyrna so far. They were not itinerant performers as their place and equipment were recorded on the wall of the room.

\section{Place inscriptions}

Three inscriptions on the western and northern walls of the room M5 in the 1st floor of the stage building in the theatre of Smyrna were recorded on the edge band of blocks.

Date: Roman Imperial Period as per lettering. Lunate sigma and epsilon.

Block A. W: $33.4 \mathrm{~cm}$; Lh: $5.3-5.8 \mathrm{~cm}$

[I]oùíov

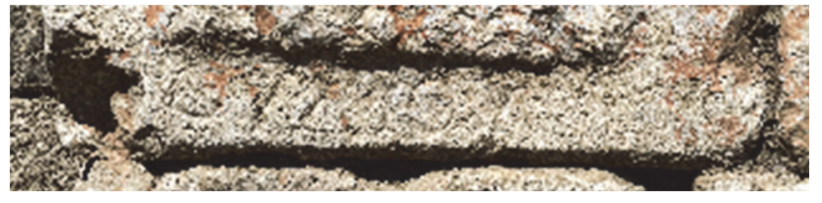

\footnotetext{
${ }^{9}$ As examples, for a group of place inscriptions in the theatre of Aphrodisias see Roueché 1993, 15-25, also see the online version at IAphrodisias 2007, 8.8, 8.9, 8.104, 8.15, 8.16, 8.17, 8.18, 8.19, 8.20, 8.21, 8.22.
} 
Block B. W: 76,2 cm; Lh: 5-6 cm

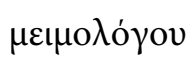

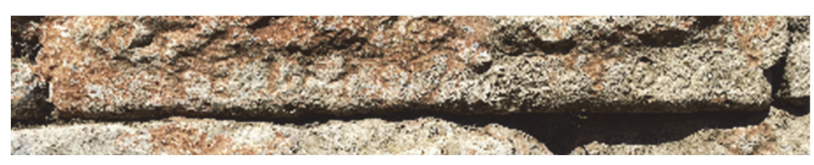

Blok C. W: $54 \mathrm{~cm}$; Lh: 4.2-5.2 cm

$\mathrm{TO}[?] \Pi \mathrm{\Pi} \Sigma$

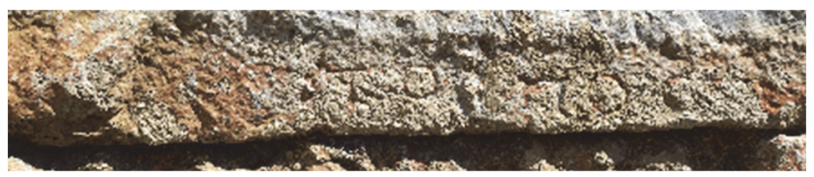

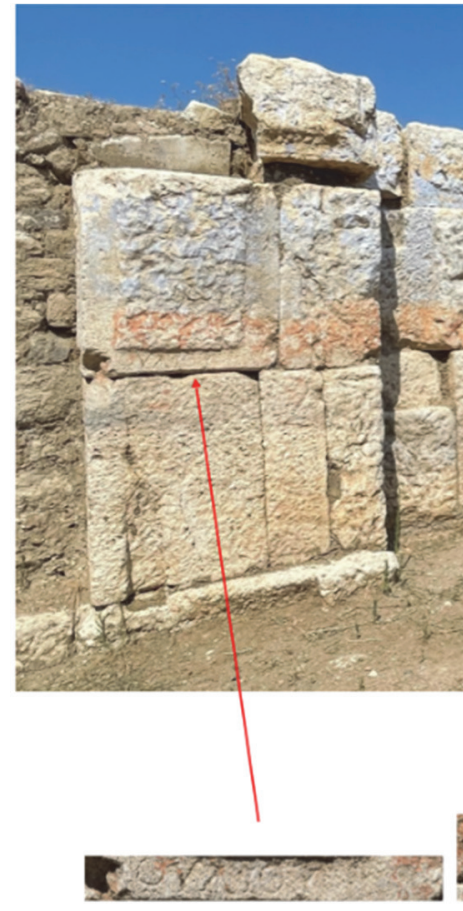

Nr.10 a

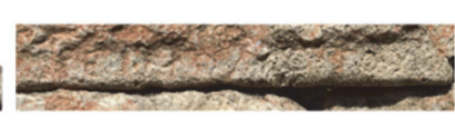

Nr. $10 \mathrm{~b}$

The contextual integrity of the inscriptions is doubtful. They are inscribed on separated blocks on western and northern walls. They may represent places for various performers, but a Sextus Iulius Paralos is known as mimologus in a funerary inscription from Smyrna. In the c block a space for one letter is missing probably because there was a flaw on the stone here. If it is complete, it seems to be то́лос. ${ }^{10}$

\section{Sundial of Hermias}

Conical sundial ${ }^{11}$ was found and noticed during the arrangements in the agora of Smyrna. It is not certain if it belonged to the group of materials unearthed in the agora of Smyrna or in the city.

\footnotetext{
${ }^{10}$ See ISmyrna I, no. 468.

${ }^{11}$ A good collection of Greek and Roman sundials can be browsed at http://repository.edition-topoi. org/collection/BSDP/overview (Accessed: 10.10.2021).
} 
Inventory: SMYRNA.4272 /SMAG.2018.29 /(Agora) KD.18.29 / Z1/A2-12/13 GRID /SURFACE (14.00 m.)

H: $30 \mathrm{~cm}$; W: $21 \mathrm{~cm}$; $: 18 \mathrm{~cm}$; Lh: $3,5 \mathrm{~cm}$.

Date: Roman imperial period

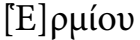

Translation: (Sundial) of Hermias.
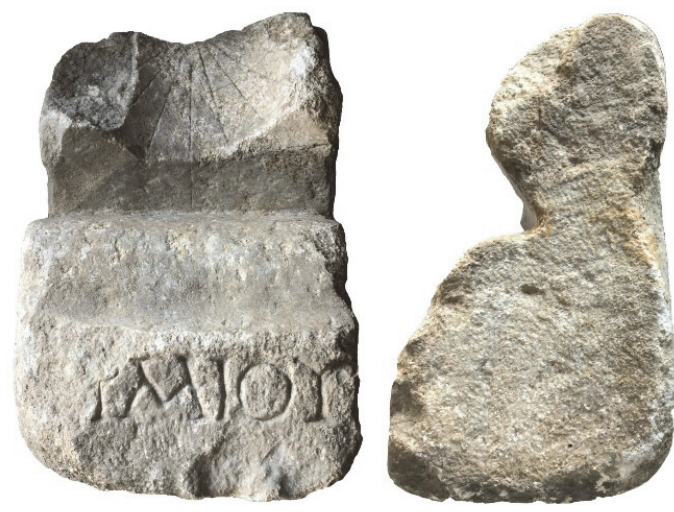

\section{A fragment}

The fragmentary inscription was found during the restoration of marble floor coverings in the Roman bath in the agora of Smyrna. It was used as a spolia reversing the inscription and flattening the surface of the block. The big letters might indicate a building inscription.

Measures: H: $27.4 \mathrm{~cm}$; W: $28 \mathrm{~cm}$. Lh: $14.1 \mathrm{~cm}$

Date: Roman imperial period as per lettering

]XOPH[

Perhaps a word derived from $\chi \circ \rho \eta \gamma \varepsilon ́ \omega$.

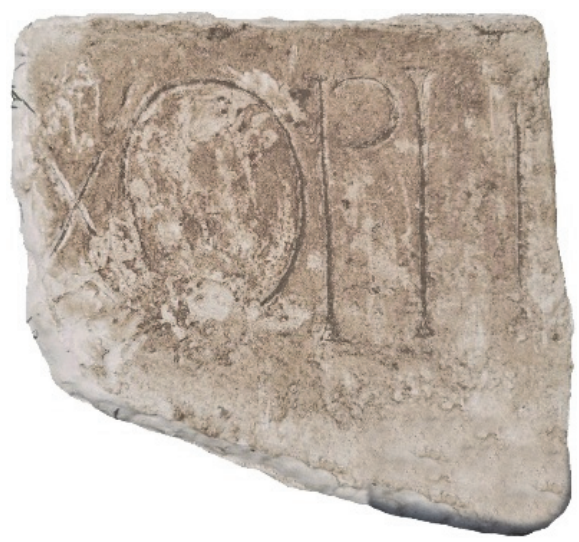

\section{Building inscription}

The inscription was recorded on two separated limestone blocks found during the theatre excavations in 2019 and 2020. They are located side by side just above the proskenion. Their exact positions in the façade of the stage building have not been determined yet. The inscription was incised on upper part of the blocks with lunate characters and slight serifs: alpha with low bar; lunate epsilon and sigma; chalice-shaped upsilon with small hasta; symmetrical $m u$ and $n u$; $p i$ with protruding horizontal and equal vertical strokes; abbreviations without punctuation; uncommon ligatures for P and KAI. Kappa for abbreviation of kaí is ligatured below the vertical bar of rho; omikron is ligatured with kappa.

\section{Block A}

Inventory: SMYRNA.4586/ SMTI.2019.41 /Tiyatro.19.40/D1-25 GRID. LEVEL: 78.37 m.

H: $22.6 \mathrm{~cm}$; W: $60.5 \mathrm{~cm}$; D: $30.9 \mathrm{~cm}$; Lh: $2.5 \mathrm{~cm}$. 


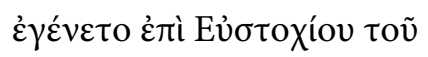

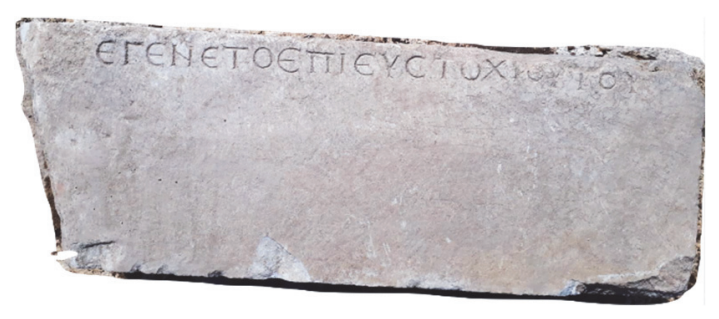

\section{Block B}

Inventory: SMYRNA.4744/ SMTİ.2020.77/Tiyatro.2020.75/D1-24 GRID. LEVEL: 78.79-78.48 m. H: $23.6 \mathrm{~cm}$; W: $73 \mathrm{~cm}$; D: $30.6 \mathrm{~cm}$. Lh: $2.5 \mathrm{~cm}$.
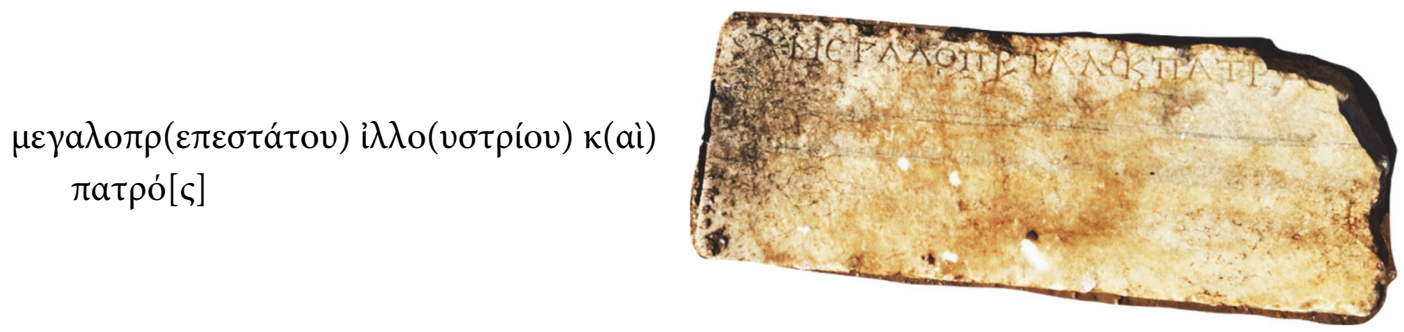

Date: the material is not from a period after the $3^{\text {rd }}$ century AD according to the archaeological material in the theatre of Smyrna. But the inscription on it does not seem to have been carved before $5^{\text {th }}$ century AD.

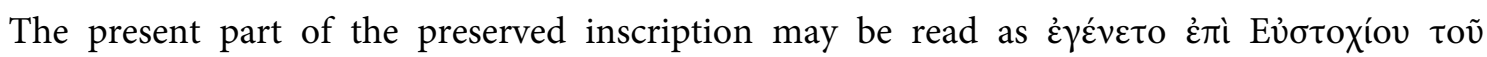

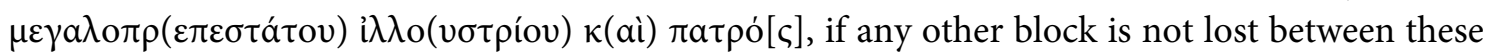

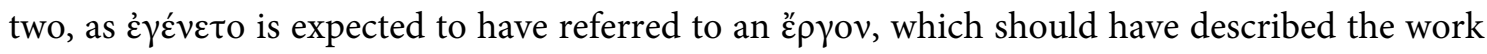
done and is missing in the surviving blocks. It might have dealt with a restoration or a construction of any part of the theatre for a later use. Eustochios is unknown person in the inscriptions

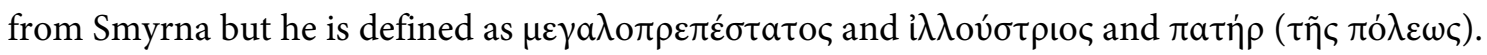
The first two of them together have been already attested in an inscription from Aphrodisias giving the meaning of magnificentissimus and illustris ${ }^{12}$. Патทं $\rho$ should be a form of pater civitatis which is generally accepted to be an official position appeared mid- $5^{\text {th }}$ century onwards ${ }^{13}$. Archaeological assessments observed so far in the theatre of Smyrna suggest that the theatre was not active after the $3^{\text {rd }}$ century $\mathrm{AD}$ onwards. However, this inscription is valuable evidence that the building was still in use in the $5^{\text {th }}$ century.

\section{Dedication to Septimius Severus and his children}

Fragmentary inscription of two lines on a cornice piece composed of a plain entablature, corona and dentil was unearthed in the theatre of Smyrna. The entablature was incised with bigger letters with straight serifs than those on the corona: alpha with right oblique stroke curving on top and straight bar in middle; non-slanting sigma; square epsilon with short middle bar; omega with curving appendices and two separate short feet below; chalice-shaped upsilon with straight short bar below oblique strokes; $p i$ with equal vertical strokes; symmetrical $m u$ and $n u$.

12 Roueché 1989 , no. 55 and plate xiii.

${ }^{13}$ When this post is created is unclear, however it is reported in a law of Leo I (Cod. Just. 10, 44, $3 ; 465$ $\mathrm{AD})$. Here it is stated that cities can give this title to decurions following their discharges. They also seem to have assisted the constructions of the cities, see Onur 2006, 196 with references and citations. See also Curchin 2014, 283 and Feissel 2017, 473-501. 
H: $45 \mathrm{~cm}$; W: $87 \mathrm{~cm}$; D: $90 \mathrm{~cm}$; Lh: $13 \mathrm{~cm}$ in upper line, $11.2 \mathrm{~cm}$ in lower line.

Date: Septimius Severus or latter

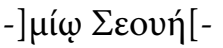

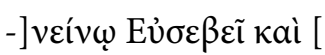

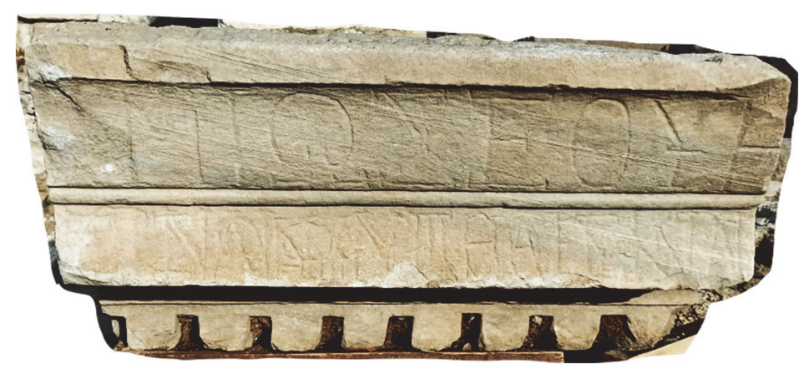

The preserved two lines of the inscription on the cornice seem to have the names of Septimius Severus and his son Caracalla as Imperator Caesar Marcus Aurelius Antoninus Pius. It is highly

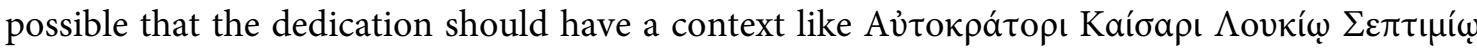

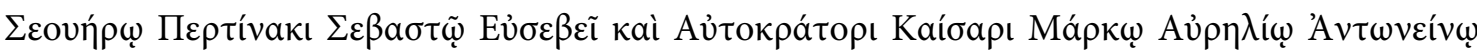

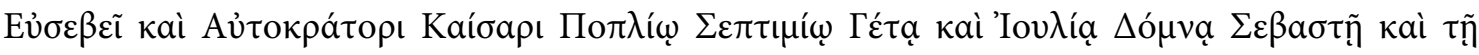

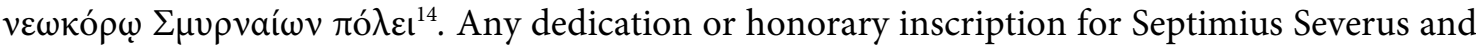
Caracalla has not been documented so far in the inscriptions from Smyrna. Other cornice pieces and fragments have not been unearthed yet as the excavation in the theatre of Smyrna is still in process.

\section{Bibliography}

Curchin 2014

L. A. Curchin, The end of local magistrates in the Roman Empire, Gerión 32, 2014, 271-287.

Ersoy - Laugier 2019

A. Ersoy - L. Laugier, Sculptures Grecques et Romaines de Smyrne, découvertes récentes, Anatolia Antiqua 27, 2019, 57-75.

Feissel 2017

D. Feissel, Trois functions municipales dans l'épigraphie protobyzantine, in K. Bolle-Ch. Witschel-C. Machado, The Epigraphic Cultures of Late Antiquity, Heidelberger althistorische Beiträge und epigraphische Studien 60, Stuttgart 2017.

Gignac 1976

F. T. Gignac, A Grammar of the Greek Papyri of the Roman and Byzantine Periods (Vols. I-II), Milano 1976.

Onur 2006

F. Onur, Some late Roman inscriptions from Side, Gephyra 3, 2006, 193-200.

Onur - Kılıç-Arslan 2021 F. Onur - S. Kılıç-Arslan, New Inscriptions from Aloanda in Lycia, Gephyra 21, 2021, 1-45.

Roueché 1989 Ch. Roueché, Aphrodisias in Late Antiquity, London 1989.

Roueché 1993

Ch. Roueché, Performers and Partisans at Aphrodisias in the Roman and late Roman Periods. A study based on inscriptions from the current excavations at Aphrodisias in Caria, London 1993.

Smyth 1956

H. W. Smyth, Greek Grammar. Revised by Gordon M. Messing. Cambridge 1956.

\footnotetext{
${ }^{14}$ For a similar dedication see IEphesos II no. 435.
} 


\section{Smyrna'dan Yeni Yazitlar \\ Özet}

En son 1990 yllında Georg Petzl tarafından Inschriften griechische Städte aus Kleinasien serisinde cilt 24,2 olarak yayınlanan Die Inschriften von Smyrna, Teil II,2: Addenda, Corrigenda und Indices, Bonn: Dr. Rudolf Habelt, eserinden sonra Smyrna agorası ve çevresinde ele geçen yeni yazıtlar yayınlanmamıştır. Bu makalede 2007 yılından itibaren Doç. Dr. Akın Ersoy başkanlığında yürütülen Smyrna agorası ve tiyatrosu kazı çalışmalarında ortaya çıkarılmış 14 yazıt ve yazıt parçacıkları ele alınarak Smyrna yazıtlar corpus una ek yapılmaktadır. Makalede ayrıca Kadifekale ve çevresinde yüzeyde ele geçmiş çeşitli yazıtlar da çalışmaya dahil edilmiştir. Yazıtların üç tanesinin gömü niteliği barizdir. Bunlarda birincisinde Apollonides'in torunu, Apollonides’in oğlu Asklepiades' in mezarı daha hayattayken kendisi, oğlu Apollonides ve azatlıları için yaptırdığı ifade edilmektedir. İkinci gömü yazıtında ise Aelius Iulius Philopator'un daha yaşadığı sırada mezarı kendisi, oğlu Iulius Philopator ve Faustus' un oğlu Lucius Rutilius Rufus için yaptırdığı kaydedilmiştir. Üçüncü gömü yazıtında ise nomen veya cognomen’i bilinmeyen Aurelia adında bir kadının mezarı kendisi, eşi, çocukları, torunları ve azatılırı için yaptırdığı dile getirilmiştir. Geri kalan yazıtlar oldukça fragman niteliktedir. Üç yazıtın niteliği tam anlaşılamamaktadır. Bunlar gömü veya onur yazıtları grubuna dahil olabilirler. Olasılıkla bir mektup parçası ve Helenistik bouleuterion a ait bir bağış̧̧ listesine ait yazıt parçası makalede ele alınmaktadır. Ayrıca güneş saati betimli bir yazıt ve hamam tabanında devşirme malzeme olarak kullanılmış bir yazıt parçasının yanı sıra tiyatro kazılarında bulunmuş mekân yazıtları ve bir korniş parçası çalışmanın kapsamını oluşturmaktadır. Tiyatro da proskenion un hemen üzerinde bulunmuş iki blok üzerinde bir yapı inşasına veya tamiratına katkı sağlayan Eustokhios isimli şahsın kentin babası olarak tanımlanması dikkat çekicidir. Tiyatroda ayrıca imparator Septimius Severus ve oğlu Caracalla nın adlarının okunabildiği bir korniş parçası Smyrna tiyatrosunun gelişim evreleri açısından değerli katkı sağlamaktadır. Tiyatroda sahne alan çeşitli aktörlere ait mekân gösteren yazıtlar da ele geçmiştir. Bunların arasında Bassus ve Selanikli çocuklara ait ekipmanlarının yer aldığı odanın tabula ansata içine alınmış bir kitabeyle gösterilmesi, bunların gezgin değil, uzun yıllar Smyrna tiyatrosunda rol alan ve çok sevilen aktörler olduklarını işaret etmektedir. Bunun dışında, Iulius ismini taşıması muhtemel bir mimologos a ait olduğu işaret edilen bir odaya da rastlanmıştır. Yazıtların Türkçe çevirileri şöyledir (5.-8., 10., 12., 14. yazıtlar anlamlı bir çeviri verilemeyecek kadar eksiktir.):

1. (Ben) Apollonides in torunu, Apollonides in oğlu Asklepiades, daha yaşadiğım sırada, (bu) mezarı kendim, oğlum Apollonides ve azatlılarım için inşa ettirdim.

2. Aelius Iulius Philopator, yaşadiğı sırada, (bu) mezarı kendisi, oğlu Iulius Philopator ve Faustus ...'nın oğlu Lucius Rutilius Rufus için (yaptırdı).

3. Aurelia El[...] (bu mezarı) kendisi ve için AN[.]O[.], çocukları, torunları ve azathlar için yaptırdı. 4. - -nophilos, evlatlı̆̆ı Thallos için - - -

9. Bassus un ve Thessalonike li çocukların ekipmanları.

11. Hermias'in (günę̧saati).

13. Çok saygı değer görkemli bir kişi ve (kentin) babası olan Eutokhius un zamanında yapılmıştır.

Anahtar Sözcükler: Smyrna, Yunanca yazıtlar, agora, tiyatro, mezar yazıtları, antik oyuncular, güneş saati, arşitrav. 


\section{New Inscriptions from Smyrna}

\section{Abstract}

The latest corpus of the inscriptions from Smyrna was published by Georg Petzl in Die Inschriften von Smyrna, Teil II,2: Addenda, Corrigenda und Indices, in series of Inschriften griechische Städte aus Kleinasien, volume 24,2, Bonn: Dr. Rudolf Habelt, in 1990. New inscriptions from Smyrna after Petzl's corpus have not been collected as addenda. In the present article it is aimed to make an addition to the corpus with the presentation of 14 inscriptions and fragments newly found during the excavations of the agora and theatre of Smyrna conducted by associate professor Akın Ersoy from İzmir Katip Çelebi University since 2007. Some inscriptions discovered around the agora and theatre, mainly at Kadifekale, but not belonging to the excavation area were also included to the study as an epigraphic material of ancient Smyrna. The inscriptions unearthed in the agora of Smyrna are mostly spolia used in the construction of different buildings over two millennia as it was occupied till to modern years. There are only three complete inscriptions and they are funeral. The rest of the inscriptions are very fragmentary. The group of the inscriptions found in the excavation of the theatre of Smyrna are subject of interest for the use and construction phases of the theatre. On a cornice piece composed of two lines the names of the Roman emperor Septimius Severus and his son Caracalla as Imperator Caesar Marcus Aurelius Antoninus Pius were identified. Two inscriptions found on the blocks of room walls in the $1^{\text {st }}$ floor of the stage building are recorded to show places of actors. One of them records instruments of Bassus and children of Thessaloniki. The other belongs to a mimologus with the name of Iulius who is attested as mimologus Iulius in a funerary inscription from Smyrna. On two blocks found above the proskenion a certain Eustochius is defined as magnificentissimus, illustris and father possibly for the father of the city.

Keywords: Smyrna, Greek inscriptions, agora, theatre, funerary inscriptions, ancient performers, sundial, architrave. 